Int. J. Electrochem. Sci., 15 (2020) $4421-4433$

International Journal of

ELECTROCHEMICAL

SCIENCE

WWW.electrochemsci.org

\title{
Electrochemical and Stress Corrosion Behaviors of 316L Stainless Steel in the Borate solution
}

\author{
Lan $\mathrm{Jin}^{1}$, Yier Guo ${ }^{2}$, Feng Liü,*, \\ ${ }^{1}$ College of Pipeline and Civil Engineering, China University of Petroleum (East China), Qingdao \\ 266580, China \\ ${ }^{2}$ College of Mechanical Engineering and Applied Electronics Technology, Beijing University of \\ Technology, Beijing 100124, China \\ ${ }^{3}$ School of Mechanical Engineering, Liaoning Shihua University, Fushun 113001, China \\ *E-mail: $\underline{\text { liuf20000@163.com }}$
}

doi: $10.20964 / 2020.05 .44$

Received: 20 December 2019 / Accepted: 19 February 2020 / Published: 10 April 2020

\begin{abstract}
The electrochemical characteristics and stress corrosion behavior of $316 \mathrm{~L}$ stainless steel in the borate solution with different $\mathrm{pH}$ were investigated through electrochemical measurements, slow strain rate tension (SSRT) tests and immersion experiments. The electrochemical measurement results indicated that borate solution will facilitate the passivation film deformation on the surface of 316L stainless steel, and the corrosion resistance of $316 \mathrm{~L}$ stainless steel decreased with the increased of $\mathrm{pH}$. While the pitting corrosion of 316L stainless steel prone to occurred in the borate solution with the value of $\mathrm{pH}$ was 11 . At the same immersion time, the number of corrosion pits increased with the $\mathrm{pH}$. Furthermore, the stress corrosion cracking (SCC) susceptibility of 316L stainless steel was tested by SSRT, and suggested that higher $\mathrm{pH}$ leads to more sensitive, and tensile fracture morphology showed the characteristic of ductile fracture when $\mathrm{pH}$ was 7 .
\end{abstract}

Keywords: 316L Stainless Steel, Borate Solution, pH, Stress Corrosion Cracking

\section{FULL TEXT}

(C) 2020 The Authors. Published by ESG (www.electrochemsci.org). This article is an open access article distributed under the terms and conditions of the Creative Commons Attribution license (http://creativecommons.org/licenses/by/4.0/). 